\title{
A rubric for assessing teachers' lesson activities with respect to TPACK for meaningful learning with ICT
}

\section{Joyce Hwee Ling Koh}

National Institute of Education, Nanyang Technological University, Singapore

Teachers' technological pedagogical content knowledge (TPACK) for meaningful learning with ICT describes their knowledge for designing ICT lesson activities with respect to five dimensions: active, constructive, authentic, intentional, and cooperative. The ICT lesson activities designed by teachers can be assessed to determine the strengths and weaknesses of their TPACK for meaningful learning with ICT in practice. This study describes the conception, validation, and implementation of a rubric for assessing ICT lesson activities with respect to the dimensions of meaningful learning with ICT. It was conducted with 55 Singaporean pre-service teachers trained to teach Chinese as a second language. The 217 lesson activities they designed during a compulsory ICT module were rated using the rubric. High ratings were obtained for the active dimension because the activities involved students using and manipulating ICT tools. However, the ratings for the other dimensions were lower because opportunities for students' personal meaning-making, exploration of real-world phenomena, collaboration through divergent knowledge construction, as well as selfdiagnosis and management of learning gaps were not as well supported in these activities. The uses of this rubric for enhancing TPACK assessment, ICT course design and the development of TPACK activity types will be discussed in the paper.

\section{Introduction}

Technological pedagogical content knowledge (TPACK) is a term used by Mishra and Koehler (2006) to encapsulate teachers' knowledge with respect to the integration of information and communication technologies (ICT) into the instruction of particular topics within a discipline area. TPACK is depicted as the area of overlap among teachers' technological knowledge, pedagogical knowledge, and content knowledge (see Figure 1), suggesting that it arises from teachers' synthesis of these three knowledge sources. The overlaps among these knowledge sources result in the intermediary knowledge sources of technological content knowledge, pedagogical content knowledge, and technological pedagogical knowledge, which are also theorized to be sources of teachers' TPACK.

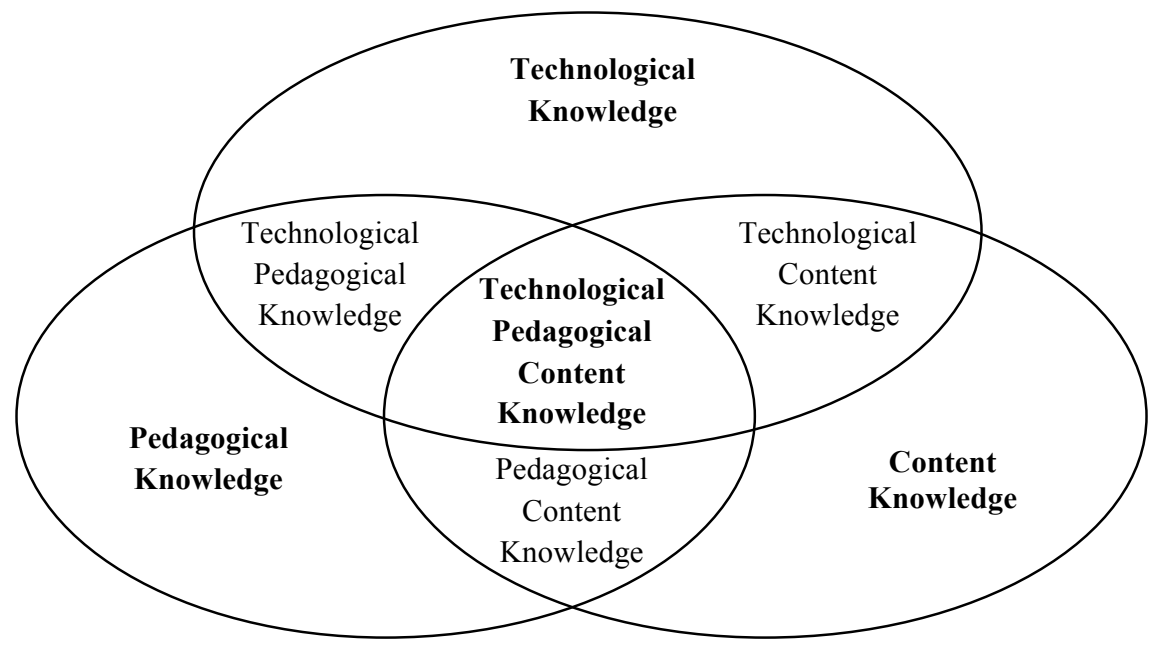

Figure 1. The TPACK Framework, as depicted by Mishra and Koehler (2006 p. 1025).

These TPACK constructs have been widely adopted as a theoretical basis for the development of survey instruments to assess teachers' ICT integration competencies (e.g., Archambault \& Barnett, 2010; Chai, Koh, \& Tsai, 2011; Koh, Chai, \& Tsai, 2010; Lee \& Tsai, 2010; Schmidt et al., 2009). These surveys assess teachers' self-reported perceptions of TPACK but may not accurately reflect their TPACK in 
practice. ICT lesson activities designed by teachers have therefore been assessed as an indication of their performance-based TPACK (Abbitt, 2011). These activities are expressions of teachers' TPACK; the outcomes of the pedagogical decisions made as teachers combine their technological, pedagogical, and content knowledge into subject-specific ICT lesson activities, which are also termed TPACK activity types (Harris, Grandgenett, \& Hofer, 2010). Therefore, rubrics developed to assess teachers' TPACK through the design of their ICT lesson activities do not measure the sources of TPACK as shown in Figure 1 but are guidelines to examine the pedagogical "fit" among technology, pedagogy, and content for specific curriculum goals in these activities (e.g., Angeli \& Valanides, 2009; Harris, et al., 2010). To date, the development and validation of rubrics to support the assessment of teachers' design of ICT lesson activities are still in their initial stages (see examples in Abbitt, 2011), which is a gap in TPACK research. The specification of TPACK activity types as expressions of content-specific TPACK is another emerging trend in TPACK research (see Harris \& Hofer, 2012).

TPACK assessment rubrics can be targeted at addressing the pedagogical dissonance teachers face when adopting constructivist teaching practices (Windschitl, 2002). An example of constructivist-oriented use of ICT is what Howland, Jonassen, and Marra (2012) termed as "Meaningful Learning with ICT" where ICT is used to engage learners in inquiry, knowledge construction, and collaboration. Such kinds of ICT lessons have long been envisioned (e.g., P21, 2007; Teo \& Ting, 2010) but are rarely attained. Empirical studies of teachers' classroom practices found that ICT has more often been used to support their current instructional practices which focus on information transmission activities (e.g., Gao, Choy, Wong, \& Wu, 2009; Lim \& Chai, 2008). These findings show that teachers generally lack the TPACK for designing meaningful learning with ICT. Currently available rubrics for TPACK assessment of ICT lesson designs are not directed at the pedagogical aims of meaningful learning with ICT. The criteria assess how lesson activities address technology standards, content standards, and content transformations with ICT (see Angeli \& Valanides, 2009; Harris, et al., 2010). A rubric for assessing TPACK for meaningful learning with ICT can address a current pedagogical challenge that teachers face. When applied to subject-specific lesson activities, it can also enhance the understanding of teachers' content-specific TPACK.

Therefore, this study aims to:

1. Explain the theoretical conceptions of a rubric to assess teachers' TPACK with respect to the five dimensions of meaningful learning as described by Howland et al. (2012);

2. Describe the development and validation of this rubric with respect to ICT lesson activities designed by 55 Singaporean pre-service teachers for a subject area; and

3. Use the rubric to analyse the strengths and weaknesses of the lesson activities designed by these teachers with respect to their TPACK for meaningful learning.

The potential use of this rubric for supporting the assessment and development of teachers' TPACK will then be discussed.

\section{Theoretical conceptions}

This section addresses the first aim of this paper by explaining the theoretical conceptions of the rubric.

\section{The five dimensions of meaningful learning with ICT}

Meaningful learning was first understood as a process whereby learners connected new information received with their pre-existing knowledge or personal experiences (Ausubel, 1960). As constructivist theories developed, the active role played by learners in meaning construction gained importance and attempts were made to distinguish rote learning from meaningful learning. The former occurred when only information was learnt (Mayer, 1999) whereas the latter involved the application of information learnt to the construction of understanding for problem-solving (Mayer, 2002). These conceptions corresponded with Howland et al. (2012) who proposed five dimensions that characterized how ICT could support "Meaningful Learning". These were: (a) active - where students were not passive listeners but actively manipulating objects and information; and observing results (b) constructive - where students constructed knowledge, reflected, and articulated their personal understandings of phenomenon (c) authentic - where students engaged in the solving of real-world problems (d) intentional - where students set their learning goals and planned their learning pathways; and (e) cooperative - where students worked with peers to learn. These dimensions were congruent with Smeets'(2005) findings that powerful learning 
experiences emerged when teachers used ICT to support environments where students worked with authentic tasks that supported active, authentic, and cooperative learning.

Howland et al. (2012) argued for the need to view technology as instruments that supported students to construct, represent, articulate, and discourse about their knowledge, that is, students learn with technology rather than from technology. Such pedagogical uses of ICT were often envisioned (e.g., P21, 2007) but not pervasively observed in classrooms. Throughout the last decade, teachers largely used ICT to augment their current pedagogical practices, serving as tools to facilitate feedback for skill-based and information regurgitation exercises, to add variation to day-to-day classroom activity, to access authentic content resources from the Internet, and to provide students with opportunities for independent work with peers (Gao, et al., 2009; Hayes, 2007; Lim \& Chai, 2008; Ruthven, Hennessy, \& Brindley, 2004; Smeets, 2005; Smeets \& Mooij, 2001; Ward \& Parr, 2010). By and large, the transformational change envisioned through innovative ICT integration has yet to be realized. Teachers need to develop the knowledge (TPACK) for designing such kinds of ICT lessons (Hennessy, Ruthven, \& Brindley, 2005; Smeets, 2005; Ward \& Parr, 2010), which can be defined using Howland et al.'s (2012) five dimensions of meaningful learning with ICT as a theoretical basis. However, these dimensions need to be further operationalized to address some of the challenges teachers face when attempting such kinds of ICT integration.

\section{TPACK for meaningful learning with ICT}

Studies of ICT lessons noted instances where they had the form but not the essence of meaningful learning (e.g., Lim \& Chai, 2008; Ruthven, et al., 2004). The following issues need to be addressed when operationalizing each dimension of teachers' TPACK for meaningful learning with ICT:

\section{Active versus constructive}

Many examples of ICT lessons involved students actively doing drill-and-practice exercises (e.g., Lim \& Chai, 2008). Jedeskog and Nissen (2004) interpreted this as surface-level ICT integration because it emphasized student engagement with ICT rather than deep engagement with the content they were learning about. Chi (2009) argued for the need to differentiate between students being active and them being constructive where the former largely involved physical activity whereas the latter involved the development of understanding. The lack of activity relegated learners as passive listeners (Schank, 1994) whereas being active did not mean that learners were being constructive if they were not engaging in activities that required them to organize, integrate, and reflect upon content knowledge; and to express ideas and interpretations beyond what was presented to them (Chi, 2009; Mayer \& Wittrock, 1996). Being constructive necessarily implied being active but not vice versa. When operationalizing teachers' TPACK for meaningful learning with ICT, it is therefore important to consider how ICT engages the constructive dimension within active learning.

\section{Independent versus intentional}

Howland et al. (2012) conceptualized the intentional dimension as one involving students in the regulation of their own learning. However, ICT was more often used to support student independent work through information search or drill-and-practice activities (Smeets, 2005), which better reflected what Zimmerman and Campillo (2003) described as self-instruction. It precluded the other self-regulatory processes such as student goal-setting, strategy planning, metacognitive monitoring, and self-evaluation. The intentional dimension of teachers' TPACK for meaningful learning with ICT therefore needs to contain evidence of how teachers' lesson activities can support students to continually engage in the diagnosis, evaluation, and improvement of their learning gaps with ICT.

\section{Authenticity through finding personal meaning}

Brown, Collins, and Duguid (1989) premised that situated learning involved learning in authentic contexts which then facilitated knowledge transfer to the real-world. ICT tools such as videos and simulations can be used to situate students' learning and problem-solving within real-world phenomenon, thereby enhancing their knowledge transfer. Merrill (2002), when articulating his "First Principles of Instruction", emphasized that effective instruction included opportunities for students to find personal applications of their learning experiences. Another way of enhancing the authenticity of students' learning would therefore involve experiences that help them to connect their personal experiences to real-world phenomenon. ICT lesson activities stronger in the authentic dimension of meaningful learning must therefore be designed to support personal meaning-making (Ellis, Barrett, Higa, \& Bliuc, 2011), which is 
another critical aspect to consider when operationalizing teachers' TPACK for meaningful learning with ICT.

Convergent versus divergent knowledge expression with peers

Howland et al. (2012) emphasized meaning negotiation and knowledge building with peers. Such kinds of interaction could be more effectively sustained through what Harris et al. (2009) described as divergent knowledge expression where students extended their understanding of content knowledge through learning activities such as report writing, creation of concept maps or building of models. On the other hand, convergent knowledge expression types focusing on the reproduction of content knowledge presented by the teacher may curtail the breadth of meaning negotiation amongst students. Therefore, group work based on convergent tasks may not necessarily enhance the constructive and cooperative dimensions of meaningful learning as compared to those structured to support divergent knowledge expressions. ICT lesson activities that support group work with divergent tasks would better exemplify the application of the cooperative dimension of TPACK for meaningful learning with ICT.

Existing TPACK assessment rubrics are designed with different aims of use and are therefore not directly transferable to the assessment of TPACK for meaningful learning with ICT. Angeli and Valanides' (2009) rubric measured teachers' TPACK for using ICT to transform complex and difficult content in ways that facilitated students' understanding. It comprised five criteria to assess the selection of appropriate lesson topics, content representations, lesson strategies, infusion strategies, and ICT tools for this purpose. Harris et al.'s (2010) rubric was targeted at TPACK in general. Its four criteria examined the selection of ICT tools, if technology appropriately supported curriculum goals, instructional strategies as well as the congruence of content, pedagogy, and technology.

Nevertheless, existing rubrics measured the variation of each criterion through a rating scale. Each lesson activity was also rated with all criteria to inform different aspects of the associated TPACK. These two features were used to guide the design and implementation of the rubric in this study. Firstly, each criterion in the rubric was rated on a five-point scale to better capture the gradations in teachers' TPACK. Secondly, each lesson activity was rated for each of the five dimensions as these represent critical aspects of their TPACK for meaningful learning with ICT as described by Howland et al.'s (2012) theoretical model.

\section{Rubric development and validation}

This section addresses the second aim of this paper, which is to describe the development and validation of the rubric.

\section{Data source}

The data for this study comprised lesson plans collected from two tutorial groups of 55 pre-service teachers who were attending a compulsory 12-week ICT module as part of their Postgraduate Diploma in Education programme at a teacher training institute in Singapore. In Singapore, all teachers are trained to teach two curriculum subjects except for those specializing in Mother Tongue Languages such as Chinese. Cox and Graham (2009) emphasized the need to approach TPACK as describing subjectspecific rather than general ICT instructional strategies. Since only the tutorial groups for Mother Tongue Languages comprised teachers who were teaching the same subject, the two tutorial groups specializing in the teaching of Chinese as a Second Language within the cohort were purposely selected for this study. This was to control for the possible influence of subject matter on TPACK assessment. The selection of Chinese Language teachers also answered a research gap surfaced by Chai, Koh, and Tsai (2013) who did not find any TPACK studies addressing strategies for language teaching in their review.

The teachers participating in this study learnt the dimensions of meaningful learning with ICT through peer reciprocal teaching and tutor modelling during the first three weeks of the semester. For the rest of the nine weeks, teachers applied these dimensions to complete three group-based design tasks during the ICT module. In each task, they designed lesson activities to support a topic from the national syllabus by exploiting the affordances of an ICT tool to support the meaningful learning dimensions. Throughout the semester, the teachers explored three ICT tools relevant for supporting Chinese Language instruction through these tasks where each group chose their desired ICT tools in consultation with the instructor. 
The ICT tools available to the teachers included the interactive whiteboard, concept mapping software, digital storytelling tools such as Photostory, Toondoo, and Glogster; as well as tools for creating Webquests e.g., Google sites. The instructor provided formative feedback to the teachers as they worked on these tasks with respect to the appropriate exploitation of the affordances of the ICT for meaningful learning. Teachers also did class presentations to share their ICT lesson designs with each other. As the development of the rubric was still in progress during the semester, it was not introduced to these teachers.

At the end of the semester, teachers consolidated their learning experiences in an individual project where they designed an ICT-integrated lesson plan. Teachers were required to select a topic from the national syllabus that could be enhanced through the use of ICT. They then designed a 60-120 minute ICT lesson to teach the topic. Teachers needed to use one or more of the ICT tools that they were exposed to throughout the module and the activities designed needed to support the dimensions of meaningful learning with ICT. Each lesson plan was written up according to a standard template where the specific lesson activities, supporting resources and estimated instructional time were described. The teachers also wrote a 300-word rationalization of why they thought the affordances of the ICT tools selected supported the dimensions of meaningful learning with ICT. These individual lesson plans designed by teachers were collected for this study at the end of the semester as they best represented the outcomes of teachers' learning throughout the semester.

\section{Defining the rubric}

TPACK assessment rubrics needed to emphasize the fit between technology, pedagogy, and content (see Harris et al., 2010). The theoretical conceptions of TPACK for meaningful learning with ICT discussed earlier were used to develop guidelines and definitions for the five-point scale of each dimension. The following guidelines were set up to emphasize that the acquisition of subject matter (content) needed to be appropriately supported by ICT (technology) for each of Howland et al.'s (2012) five dimensions (pedagogy), which addressed the pedagogical foci of meaningful learning with ICT:

1. Active - For how long did the lesson activity engage students to manipulate information about subject matter with ICT tools? The larger percentage of activity duration spent by students in using and manipulating ICT tools to learn the subject matter, the more it was considered as active.

2. Constructive - To what extent did the use of ICT tools in the lesson activity engage students in divergent expressions of subject matter rather than convergent knowledge expressions as defined by Harris et al. (2008)? Besides engaging in divergent knowledge expressions, to what extent were these eliciting students' personal reflections about the content knowledge they were engaging with? Higher levels of the constructive dimension were indicated by knowledge expressions that were increasingly divergent and personally reflective.

3. Authentic - To what extent did the use of ICT tools in the lesson activity engage students to represent their personal applications of real-world phenomenon related to the subject matter being learnt? The more the activity facilitated students to make connections between their own experiences and the real-world phenomenon associated with the subject matter, the more it was considered as authentic.

4. Intentional - To what extent did the use of ICT tools in the lesson activity engage students to selfdiagnose and fix their learning gaps with respect to the subject matter being learnt? To what extent were these processes carried out continually throughout the lesson activity? The more the activity provided opportunities for students to engage in continual self-diagnosis and remediation of learning gaps, the more it was considered as intentional.

5. Cooperative - To what extent did the use of ICT tools for group work during the lesson activity comprise of opportunities for divergent, knowledge-building talk about the subject matter either around or through the computer? The more the activity stimulated divergent talk, the more it was considered as cooperative.

These guidelines as well as the definitions for each level of the different dimensions were first subjected to expert review for content validity. This was carried out with two educational technology faculties at an institute that had both experience with teaching Howland et al.'s (2012) framework and research expertise in TPACK. The appropriateness of the guidelines with respect to the conceptions of TPACK as well as 
the appropriateness of the different levels were reviewed. Areas of inconsistency were negotiated between the experts until there was full agreement.

\section{Data coding and inter-rater analysis}

Qualitative content analysis was used as a research methodology for this study as it catered for the analysis and meaning-making of textual data (Weber, 1990) from teachers' ICT lesson plans. It can be used to identify and evaluate the characteristics of textual data against pre-established standards (Krippendorff, 2004), which supported the objectives of this study. Lesson activities provided for the pedagogical structures in a lesson (Harris, Mishra, \& Koehler, 2009; Windschitl, 2004) and a way of understanding teachers' pedagogical conceptions. Each lesson activity defined by the teachers was considered as a unit of analysis. This was an example of what Krippendorff (2004) described as a physical unit of analysis where content can be broken down without pre-imposed meanings. Using this method, the 55 lesson plans collected from the teachers were broken down into 270 learning activities. Of these, 217 activities (80.4\%) involved the use of ICT for content instruction or student inquiry. The omission of the remaining non-ICT activities from the analysis was not expected to bias the results because these were largely short activities (5-10 minutes each) where instructions and lesson summaries were given to transition between the main ICT activities involving content instruction or student inquiry. The meaningful learning strategies designed by teachers were well indicated by the ICT activities, which comprised the majority of the total activities coded.

The author and a second coder randomly selected and rated $20 \%$ of the lesson activities independently. Cohen's kappa was computed as a measure of inter-rater reliability and the areas of disagreement were discussed and rectified. This process was repeated and after rating $40 \%$ of the lesson activities, a Cohen's kappa of at least 0.80 was obtained (active: 0.93 , constructive: 0.93 , intentional: 0.89 , authentic: 0.85 , cooperative: 92). Minor changes were made to refine the phrasing of rubric items during the process of inter-rater analysis. The final version of the rubric (See Table 1) was then used to rate all the remaining lesson activities.

\section{Assessing teachers' TPACK for meaningful learning with ICT}

This section addresses the third aim of this paper, which is to analyse the strengths and weaknesses of lesson activities designed by Chinese Language teachers when coded using the rubric.

\section{Data analysis}

Descriptive statistics for each of the five dimensions were analysed to determine the overall level of Chinese Language teachers' TPACK for meaningful learning with ICT when rated with the rubric. Harris et al. (2009) proposed that TPACK be defined within the typical genres of lesson activities of a subject area. For World Languages such as Chinese, van Olphen, Hofer, and Harris (2011, February) identified listening, speaking, reading, writing, and viewing to be the key TPACK genres. To better pinpoint the strengths and weaknesses of teachers' design in teachers' TPACK for meaningful learning with ICT, the lesson activities were further classified by van Olphen et al.'s genres for World Languages. Within each genre, the means of the five dimensions were compared. Qualitative interpretations of these differences were then carried out by analysing the common design characteristics among the lesson activities.

\section{Levels of teachers' TPACK for meaningful learning with ICT}

The overall means in Table 2 indicated unequal ratings among the dimensions. Several aspects of teachers' TPACK for meaningful learning with ICT were observed from the results. The overall mean rating for the Active dimension was the highest among all dimensions $(M=2.53)$. In terms of the active dimension, the activities designed engaged students with ICT use for a substantial portion of the activity duration. The next highest rating was for the constructive dimension $(M=1.87)$. The activities had some elements of divergent knowledge expression but lacked the element of reflection, which also indicated why the ratings for the authentic and the cooperative dimensions were only close to 1.5 . The activities were rated lowest for the intentional dimension, with a mean rating below 1 . This was because the activities designed did not sufficiently exploit ICT for self-diagnosis and rectification of learning gaps. 
Table 1

Rubric for assessing TPACK for meaningful learning with ICT

\begin{tabular}{|c|c|c|c|c|c|}
\hline Dimension & 0 & 1 & 2 & 3 & 4 \\
\hline Active & $\begin{array}{l}\text { Students passively receive } \\
\text { subject matter from media or } \\
\text { ICT all the time }\end{array}$ & $\begin{array}{l}\text { There is sporadic use of } \\
\text { ICT tools by students to } \\
\text { work with subject matter }\end{array}$ & $\begin{array}{l}\text { Students are using ICT to } \\
\text { work with subject matter half } \\
\text { the time }\end{array}$ & $\begin{array}{l}\text { There is substantial use of ICT } \\
\text { by students to work with subject } \\
\text { matter. }\end{array}$ & $\begin{array}{l}\text { Almost all lesson time } \\
\text { involves students using ICT } \\
\text { to work with subject matter. }\end{array}$ \\
\hline Constructive & $\begin{array}{l}\text { ICT tools used for } \\
\text { transmission of subject matter } \\
\text { rather than meaning-making. }\end{array}$ & $\begin{array}{l}\text { ICT tools used to support } \\
\text { reproduction of subject } \\
\text { matter or convergent } \\
\text { knowledge expression by } \\
\text { students. }\end{array}$ & $\begin{array}{l}\text { ICT used to support some } \\
\text { degrees of divergent } \\
\text { knowledge expression by } \\
\text { students with respect to the } \\
\text { subject matter. }\end{array}$ & $\begin{array}{l}\text { ICT tools used by students to } \\
\text { synthesize information in order } \\
\text { to construct verbal, written, } \\
\text { visual, conceptual or product- } \\
\text { oriented expressions of the } \\
\text { subject matter. }\end{array}$ & $\begin{array}{l}\text { ICT tools used by students } \\
\text { to articulate their personal } \\
\text { reflections of subject matter } \\
\text { in the form of verbal, } \\
\text { written, visual, conceptual } \\
\text { or product-oriented } \\
\text { expressions. }\end{array}$ \\
\hline Authentic & $\begin{array}{l}\text { No representations of real- } \\
\text { world phenomenon or } \\
\text { problems related to the } \\
\text { subject matter are presented } \\
\text { with ICT tools. }\end{array}$ & $\begin{array}{l}\text { ICT tools used to present } \\
\text { examples of real-world } \\
\text { phenomena related to the } \\
\text { subject matter of } \\
\text { students. }\end{array}$ & $\begin{array}{l}\text { ICT tools support students to } \\
\text { investigate real-world } \\
\text { phenomena or problems } \\
\text { related to the subject matter. }\end{array}$ & $\begin{array}{l}\text { A problem associated with a } \\
\text { real-world phenomenon related } \\
\text { to the subject matter is used to } \\
\text { anchor the activity and students } \\
\text { investigate the real-world } \\
\text { phenomenon with ICT tools in } \\
\text { order to propose solutions. }\end{array}$ & $\begin{array}{l}\text { Students represent their } \\
\text { personal experiences of the } \\
\text { real-world phenomenon/ } \\
\text { problem related to the } \\
\text { subject matter with ICT } \\
\text { tools }\end{array}$ \\
\hline Intentional & $\begin{array}{l}\text { Students do not use ICT tools } \\
\text { to support them in } \\
\text { diagnosing, strategizing about } \\
\text { or improving their learning } \\
\text { gaps of the subject matter. }\end{array}$ & $\begin{array}{l}\text { Students' learning gaps of } \\
\text { the subject matter are } \\
\text { being diagnosed by } \\
\text { teachers or peers. }\end{array}$ & $\begin{array}{l}\text { Students self-diagnose their } \\
\text { learning gaps of the subject } \\
\text { matter by using ICT } \\
\text { tools/resources. }\end{array}$ & $\begin{array}{l}\text { Students use ICT tools/resources } \\
\text { to self-diagnose their learning } \\
\text { gaps of the subject matter. } \\
\text { Thereafter, they are to fix these } \\
\text { learning gaps. }\end{array}$ & $\begin{array}{l}\text { Students continually use } \\
\text { ICT-based tools/resources to } \\
\text { self-diagnose and fix their } \\
\text { learning gaps of the subject } \\
\text { matter. }\end{array}$ \\
\hline Cooperative & $\begin{array}{l}\text { No cooperative activity over } \\
\text { ICT platforms/tools or ICT } \\
\text { tools/platforms are used to } \\
\text { share information and } \\
\text { resources related to the } \\
\text { subject matter but no online } \\
\text { discussion occurs. }\end{array}$ & $\begin{array}{l}\text { Students work together } \\
\text { either around the } \\
\text { computer or through the } \\
\text { computer in activities } \\
\text { requiring convergent } \\
\text { knowledge expressions of } \\
\text { the subject matter. }\end{array}$ & $\begin{array}{l}\text { Students work together either } \\
\text { around the computer or } \\
\text { through the computer in } \\
\text { activities requiring some } \\
\text { degree of divergent } \\
\text { knowledge expression of the } \\
\text { subject matter. }\end{array}$ & $\begin{array}{l}\text { Students work together either } \\
\text { around the computer or through } \\
\text { the computer in activities } \\
\text { requiring a large degree of } \\
\text { divergent knowledge expression } \\
\text { of the subject matter. }\end{array}$ & $\begin{array}{l}\text { Students work together } \\
\text { either around the computer } \\
\text { or through the computer in } \\
\text { activities requiring primarily } \\
\text { divergent knowledge } \\
\text { expression of the subject } \\
\text { matter. }\end{array}$ \\
\hline
\end{tabular}


Table 2

TPACK for meaningful learning with ICT Ratings

\begin{tabular}{lllllll}
\hline & $\begin{array}{l}\text { Reading } \\
(N=21)\end{array}$ & $\begin{array}{l}\text { Speaking } \\
(N=36)\end{array}$ & $\begin{array}{l}\text { Listening } \begin{array}{l}\text { Viewing } \\
(N=40)\end{array} \\
\text { Active }\end{array}$ & $\begin{array}{l}\text { Writing } \\
(N=83)\end{array}$ & $\begin{array}{l}\text { Evaluation } \\
(N=37)\end{array}$ & $\begin{array}{l}\text { Overall } \\
(N=217)\end{array}$ \\
& $S D=0.86$ & $M=0.44$ & $M=0.43$ & $M=3.82$ & $M=3.22$ & $M=2.53$ \\
Constructive & $M=1.90$ & $S D=1.05$ & $S D=1.22$ & $S D=0.72$ & $S D=1.44$ & $S D=1.86$ \\
& $S D=0.70$ & $S D=1.34$ & $S D=1.01$ & $S D=0.78$ & $S D=1.27$ & $M=1.87$ \\
Authentic & $M=0.48$ & $M=0.97$ & $M=0.68$ & $M=2.47$ & $M=0.24$ & $M=1.32$ \\
& $S D=0.98$ & $S D=1.23$ & $S D=1.23$ & $S D=1.52$ & $S D=0.86$ & $S D=1.58$ \\
Intentional & $M=1.10$ & $M=0.31$ & $M=0.15$ & $M=0.77$ & $M=1.70$ & $M=0.77$ \\
& $S D=0.70$ & $S D=0.58$ & $S D=0.43$ & $S D=0.90$ & $S D=0.62$ & $S D=0.88$ \\
Cooperative & $M=1.62$ & $M=0.08$ & $M=0.08$ & $M=2.35$ & $M=0.92$ & $M=1.24$ \\
& $S D=1.02$ & $S D=0.37$ & $S D=0.47$ & $S D=1.69$ & $S D=1.30$ & $S D=1.58$ \\
\hline
\end{tabular}

\section{Strengths and weaknesses in teachers' TPACK for meaningful learning with ICT for Chinese Language instruction}

When analysed by van Olphen et al.'s (2011) genres, close to $40 \%(N=83)$ of the lesson activities were related to Writing whereas only about $17 \%(N=36)$ were related to Speaking (see Table 2). With the use of multimedia presentations such as YouTube videos and PowerPoint, Listening and Viewing lesson activities tend to occur in tandem. Therefore, these two genres were merged and it comprised about $18 \%(N=40)$ of the total lesson activities. The genre of reading comprised only about $10 \%(N=21)$ of the total lesson activities. Interestingly, a new genre, evaluation had to be created in this study to account for lesson activities involving the review and revision of lesson content. This genre was fairly large as it comprised about $17 \%(N=37)$ of the total lesson activities.

\section{Reading}

Reading activities largely involved the analysis of comprehension texts. ICT tools such as mind mapping tools (e.g., bubbl.us), online stickies (e.g., LinoIT, WallWisher), and GoogleDocs were used to support the creation of summaries and 5W1H (Who, What, When, Why, Where, How) structures. The active dimension had the highest mean rating among all dimensions. This was because ICT tools were used throughout the activity duration to support text comprehension. The next highest rating was for the constructive dimension. Nevertheless, its mean rating was only close to 2 because no activities required the stories or new vocabularies introduced in the prescribed texts to be related to students' personal life experiences. In addition, no real-world phenomenon or problems related to the text content were being presented to students. Therefore, the authentic dimension was rated below 1. Even though group work was indicated, these involved convergent meaning-making where comprehension questions were to be answered and model answers were eventually to be reviewed by teachers. Therefore, the ratings of the intentional and cooperative dimensions were both below 2 .

\section{Speaking}

The speaking activities largely involved the use of PowerPoint and the interactive whiteboard to provide stimulus information for students to do choral reading of new vocabulary words, sentences, and comprehension texts. The lack of divergent knowledge expressions resulted in the mean rating for the constructive dimension to be below 1.5 even though it was the highest among all dimensions. The mean ratings of the active, authentic, intentional, and cooperative dimensions were below 1 as the activities did not involve the manipulation of information with ICT, discussion of real-world phenomena, peer evaluation, or group discussions respectively.

\section{Listening and viewing}

In listening and viewing activities, ICT platforms such as PowerPoint, interactive whiteboards, YouTube videos or online portals were used to present stimulus materials to students. The mean ratings for all dimensions were below 1 because the activities involved presenting information with ICT tools rather than the comprehension and discussion of the information presented. 


\section{Writing}

ICT tools such as GoogleDocs, bubbl.us, and blogger.com were used to support the note-taking of results from web searches, and the writing of sentences, paragraphs, letters, memos, emails and journals. The practice of writing was also incorporated into the creation of multimedia products with tools such as Photostory, Audacity, and PowerPoint. The dimensions of meaningful learning with ICT were well-exploited in the writing activities. The active dimension had the highest mean rating because these ICT tools were used to support the development of written expressions throughout the activity durations. The constructive, authentic, and cooperative dimensions all had mean ratings close to or above 2.5. This was because the writing activities involved the manipulation and synthesis of information about real-world phenomena from Internet searches; and use of the synthesized information to formulate stories, reports, or multimedia presentations. Such kinds of activities moved away from information reproduction and better facilitated divergent knowledge construction during group work. The intentional dimension had the lowest mean rating that was below 1 as the use of ICT tools to support self-diagnosis and improvement of writing was rare.

\section{Evaluation}

Evaluation activities involved the assessment of learning gaps through online quizzes or feedback from teachers and peers that were posted on Facebook (for Secondary school lesson plans), EDMODO (for Primary school lesson plans) or blogger.com. The active dimension had the highest mean rating of above 3 because the activities were conducted with ICT tools. The constructive and intentional dimensions had the next highest ratings that were more than 1.5 but less than 2 . This was because online quizzes were used to support drill-andpractice of content information, which did not have much scope for stimulating divergent knowledge expressions. Its automated feedback helped students to self-diagnose knowledge gaps but such kinds of activities were not prescribed continually. The mean rating for the cooperative dimension was below 1. Even though the activities incorporated online posting of peer feedback, the online platforms were not exploited to further peer discussions which in turn curtailed the opportunities for higher levels of cooperation. The mean rating for the authentic dimension was below 1 because the activities emphasized the recall of content information rather than deeper extensions through the discussion of real-world applications.

Assessment of the design of lesson activities with respect to TPACK for meaningful learning with ICT found the design of speaking, and listening and viewing activities to be the weakest among the genres. One reason could be because of the strong conception of the importance of basic skills such as pronunciation and character recognition in Chinese language learning (Everson, 1994). The instructional intent could have led teachers to focus more on convergent types of knowledge expression for these genres while placing more emphasis on divergent knowledge expressions in writing activities.

\section{Discussion}

Educational rubrics provide clarity for performance standards and enhance the quality of educational assessment (Arter \& McTighe, 2001; Jonsson \& Svingby, 2007). The development of TPACK assessment rubrics by Angeli and Valanides (2009) and Harris et al. (2010) provide teachers with guidelines to consider the pedagogical fit of technology, pedagogy, and content as theorized by Mishra and Koehler (2006). This study contributes to the development of TPACK assessment rubrics by focusing on the aspect of TPACK for meaningful learning with ICT. It is one way of helping teachers transition their practice towards the constructivist uses of ICT that have been envisioned in many strategic master plans for education (e.g., P21, 2007; Teo \& Ting, 2010). This rubric can be used to support the following aspects of teacher education:

\section{Enhancing TPACK assessment in teacher education}

TPACK assessment is becoming more important as the TPACK framework is increasingly being accepted as a theoretical basis for the planning of ICT courses in teacher education programmes (Koh, et al., 2010). To address the specific needs of teacher education programmes, TPACK surveys are increasingly being contextualized for specific content areas (e.g., Graham et al., 2009for Science Education) and specific pedagogies (e.g., Archambault \& Crippen, 2009 for online facilitation). In a review of TPACK assessment, Abbitt (2011) emphasized the need for TPACK surveys to be supported by corresponding assessment of teachers' ICT lesson plans. This provides a comprehensive understanding of teachers' TPACK development throughout teacher education from both their perceptions and lesson design. A survey instrument to assess TPACK for meaningful learning has been progressively validated and used for the TPACK assessment of 
Singapore pre-service teachers attending teacher education programmes (Chai, Koh, \& Tsai, 2010; Chai, et al., 2011). The relationship between teachers' TPACK perceptions and TPACK-in-action can be better examined by incorporating the rubric developed in this study into teachers' TPACK assessment. This contributes to a more comprehensive assessment of teachers' TPACK development throughout their teacher education.

\section{Enhancing TPACK development in ICT courses}

This rubric can contribute towards the improvement of ICT courses. The findings of this study suggest that the ICT module was successful in developing the teachers' TPACK for meaningful learning with ICT for the active dimension as well as Levels 1 and 2 of the other dimensions. Their weaknesses at conceptualizing lesson activities beyond Level 2 of the constructive, authentic, intentional, and cooperative dimensions could be because these teachers were insufficiently exposed to such kinds of learning experiences as students, given that Singaporean classroom practices are largely teacher-centric and focused on information acquisition for exam preparation (Gao, et al., 2009; Hogan \& Gopinathan, 2008; Lim \& Chai, 2008). The transition from teacherdirected to more constructivist modes such as those espoused in the meaningful learning dimensions often present teachers with conceptual dilemmas, especially when such pedagogies are not widely adopted in school systems (Windschitl, 2002). Therefore, teachers may need more time to develop what Shulman (1999) termed as pedagogical reasoning. In this case, teachers need to develop the associated pedagogical reasoning to design meaningful learning with ICT. The rubrics developed in this study, when taught expressly to pre-service teachers, can be used as a design scaffold to help them address these pedagogical difficulties. The findings of this study suggest that more emphasis needs to be given to Levels 3 and 4 of the various dimensions during tutor modelling which were the teachers' areas of weakness. The rubric also surfaces the strengths and weaknesses of teachers' TPACK with respect to content-specific activity genres, which can inform the instruction of this module to subject-specific tutorial groups.

\section{Developing TPACK activity types}

Besides supporting ICT lesson evaluation, the collection and coding of lesson plans with the rubric can lead to the amalgamation of lesson activities within a discipline that typify meaningful learning. This was what Harris et al. (2009) described as TPACK learning activity types, which are typical ICT lesson activities within a discipline that teachers can combine or adapt to formulate their ICT lessons. Throughout time, discipline-based TPACK for supporting meaningful learning with ICT can be developed. This in turn can be used as an exemplar to support teacher education and development. Especially for constructivist-oriented modes of instruction such as meaningful learning with ICT, such kinds of exemplars are useful for addressing teachers' pedagogical dissonance (Windschitl, 2002). In this study, some groundwork for the TPACK activity genres of Chinese Language instruction has been laid. Further coding of the lesson activities can be done to develop more detailed activity type descriptions within each genre.

\section{Limitations and future research}

This study has several limitations. Firstly, the results were based on content analysis of the lesson plans designed by the teachers. While the teachers' rationale for implementing the dimensions of meaningful learning were also referred to while coding the lesson plans, one-to-one interviews were not conducted as it was outside the scope of this study. This may have limited the opportunity to probe more deeply into teachers' rationale for the design of the lesson activities. Secondly, the teachers chose their lesson topic and activities. Therefore, the activity types discussed in this study did not represent all the possible genres or activity types for the instruction of the Chinese Language. Thirdly, the ratings were derived from 55 pre-service teachers trained to teach the Chinese Language. These may not be representative of pre-service teachers trained for other subject areas or inservice teachers. Finally, this rubric was only used to assess Chinese Language lesson activities designed by preservice teachers. Its suitability for other subject areas, as well as activities designed by in-service teachers has yet to be examined. Therefore, validity of the rubric beyond the context of this study cannot be claimed.

These limitations present opportunities for several areas of future research. Firstly, the rubric needs to be further validated with more lesson plans developed by both pre-service and in-service teachers and with a variation of subject content. Besides content analysis, one-to-one interviews can be conducted with these teachers to better understand their rationales for lesson design. Secondly, action research studies can be conducted with in-service teachers where the rubric be used to scaffold the design of ICT lessons. This can provide insights about the applicability of the rubric in school-settings, especially the practical feasibility of advanced levels in each dimension. This can be used to refine the rubric. Thirdly, pre-service teachers' TPACK for meaningful learning with ICT before and after using the rubric can be compared to assess its efficacy as a design scaffold. Due to the 
nature of their project requirements, the majority of the lesson activities designed by teachers in this study were ICT activities. An analysis of the interaction between ICT and non-ICT activities within teachers' lesson designs and how these contributed to students' meaningful learning experience was outside the scope of this study, but is another area of future research that could be considered. Finally, the rubric can be used to guide the development of TPACK activity types for supporting constructivist-oriented instruction in different subject areas.

\section{Conclusion}

This study described a rubric that can be used to assess ICT lesson activities with respect to TPACK for meaningful learning with ICT. Through this process, the strengths and weaknesses of teachers' conceptions of constructivist-oriented ICT activities can be pinpointed. The rubric can also serve as a pedagogical scaffold to help teachers transition towards constructivist-oriented ICT integration. It is a useful tool for supporting teachers' TPACK development that is worthy of further analysis.

\section{Acknowledgement}

This paper refers to data from the research project "Understanding And Profiling Teachers' Technological Pedagogical Content Knowledge (TPACK) Development Patterns" (OER12/10/KHL), funded by the Education Research Funding Programme, National Institute of Education (NIE), Nanyang Technological University, Singapore. The views expressed in this paper are the authors' and do not necessarily represent the views of NIE.

The author would also like to thank Associate Professor Chai Ching Sing for his comments and critique during the formulation of the rubric as well as the conceptualization of the paper.

\section{References}

Abbitt, J. T. (2011). Measuring technological pedagogical content knowledge in preservice teacher education: A review of current methods and instruments. Journal of Research on Technology in Education, 43(4), 281.

Angeli, C., \& Valanides, N. (2009). Epistemological and methodological issues for the conceptualization, development, and assessment of ICT-TPCK: Advances in technological pedagogical content knowledge (TPCK). Computers \& Education, 52(1), 154-168.

Archambault, L. M., \& Barnett, J. H. (2010). Revisiting technological pedagogical content knowledge: Exploring the TPACK framework. Computers \& Education, 55(4), 1656-1662. doi: 10.1016/j.compedu.2010.07.009

Archambault, L. M., \& Crippen, K. (2009). Examining TPACK among K-12 online distance educators in the United States. Contemporary Issues in Technology and Teacher Education, 9(1). Retrieved from http://www.citejournal.org/vol9/iss1/general/article2.cfm

Arter, J., \& McTighe, J. (2001). Scoring rubrics in the classroom. Thousand Oaks: Corwin Press Inc.

Ausubel, D. P. (1960). The use of advance organizers in learning and retention of meaningfu material. Journal of Educational Psychology, 51, 262-272.

Brown, J., Collins, A., \& Duguid, P. (1989). Situated cognition and the culture of learning. Educational Researcher, 18(4), 32-42.

Chai, C. S., Koh, J. H. L., \& Tsai, C. C. (2010). Facilitating preservice teachers' development of technological, pedagogical, and content knowledge (TPACK). Educational Technology and Society, 13(4), 63-73.

Chai, C. S., Koh, J. H. L., \& Tsai, C. C. (2011). Exploring the factor structure of the constructs of technological, pedagogical, content knowledge (TPACK). The Asia-Pacific Education Researcher, 20(3), 595-603.

Chai, C. S., Koh, J. H. L., \& Tsai, C.-C. (2013). A review of technological pedagogical content knowledge. Education Technology and Society, 16(2), 31-51. 
Chi, M. T. H. (2009). Active-constructive-interactive: A conceptual framework for differentiating learning activities. Topics in Cognitive Science, 1(1), 73-105.

Cox, S., \& Graham, C. R. (2009). Diagramming TPACK in practice: Using and elaborated model of the TPACK framework to analyse and depict teacher knowledge. TechTrends, 53(5), 60-69.

Ellis, R. A., Barrett, B. F. D., Higa, C., \& Bliuc, A. M. (2011). Student experiences of learning technologies across the Asia Pacific region. Asia-Pacific Education Researcher, 20(1), 103-117.

Everson, M. E. (1994). Toward a process view of teaching reading in the second language Chinese curriculum. Theory into Practice, 33(1), 4-9.

Gao, P., Choy, D., Wong, A. F. L., \& Wu, J. (2009). Developing a better understanding of technology based pedagogy. Australasian Journal of Educational Technology, 25(5), 714-730. Retrieved from http://www.ascilite.org.au/ajet/ajet25/gao.html

Graham, R. C., Burgoyne, N., Cantrell, P., Smith, L., St. Clair, L., \& Harris, R. (2009). Measuring the TPACK confidence of inservice Science teachers. TechTrends, 53(5), 70-79.

Harris, J., Grandgenett, N., \& Hofer, M. (2010, March). Testing a TPACK-based technology integration assessment rubric. In D. Gibson \& B. Dodge (Eds.), Proceedings of Society for Information Technology \& Teacher Education International Conference 2010 (pp. 3833-3840).

Harris, J., \& Hofer, M. (2012). Learning activity types wiki. Retrieved from http://activitytypes.wmwikis.net/

Harris, J., Mishra, P., \& Koehler, M. (2009). Teachers' technological pedagogical content knowledge and learning activity types: Curriculum-based technology integration reframed. Journal of Research on Technology in Education, 41(4), 393-416.

Hayes, D. N. A. (2007). ICT and learning: Lessons from Australian classrooms. Computers \& Education, 49(2), 385-395.

Hennessy, S., Ruthven, K., \& Brindley, S. (2005). Teacher perspectives on integrating ICT into subject teaching: commitment, constraints, caution, and change. Journal of Curriculum Studies, 37(2), 155-192.

Hogan, D., \& Gopinathan, S. (2008). Knowledge management, sustainable innovation, and pre-service teacher education in Singapore. Teachers and Teaching: Theory and Practice, 14(4), 369-384.

Howland, J. L., Jonassen, D., \& Marra, R. M. (2012). Meaningful learning with technology (4th ed.). Boston, MA: Allyn \& Bacon.

Jedeskog, G., \& Nissen, J. (2004). ICT in the classroom: Is doing more important than knowing? Education and Information Technologies, 9(1), 37-45.

Jonsson, A., \& Svingby, G. (2007). The use of scoring rubrics: Reliability, validity and educational consequences. Educational Research Review, 2(2), 130-144.

Koh, J. H. L., Chai, C. S., \& Tsai, C. C. (2010). Examining the technology pedagogical content knowledge of Singapore pre-service teachers with a large-scale survey. Journal of Computer Assisted Learning, 26(6), 563-573.

Krippendorff, K. (2004). Content analysis: An introduction to its methodology. Thousand Oaks, California: SAGE Publications.

Lee, M. H., \& Tsai, C. C. (2010). Exploring teachers' perceived self efficacy and technological pedagogical content knowledge with respect to educational use of the World Wide Web. Instructional Science, 38, 1-21.

Lim, C. P., \& Chai, C. S. (2008). Teachers' pedagogical beliefs and their planning and conduct of computermediated classroom lessons. British Journal of Educational Technology, 39(5), 807-828. 
Mayer, R. E. (1999). The promise of educational psychology. Upper Saddle River, NJ: Prentice-Hall.

Mayer, R. E. (2002). Rote versus meaningful learning. Theory into practice, 41(4), 226-232.

Mayer, R. E., \& Wittrock, M. C. (1996). Problem-solving transfer. In D. C. Berliner \& R. C. Calfee (Eds.), Handbook of educational psychology (pp. 47-62). New York: Macmillan.

Merrill, M. D. (2002). First principles of instruction. Educational Technology Research and Development, 50(3), 43-59.

Mishra, P., \& Koehler, M. J. (2006). Technological pedagogical content knowledge: A framework for teacher knowledge. Teachers College Record, 108(6), 1017-1054.

P21. (2007). Maximizing the impact: The pivotal role of technology in a 21 st century education system. Retrieved from http://www.p21.org/documents/p21 setdaistepaper.pdf

Ruthven, K., Hennessy, S., \& Brindley, S. (2004). Teacher representations of the successful use of computerbased tools and resources in secondary-school English, Mathematics and Science. Teaching and Teacher Education, 20(3), 259-275.

Schank, R. C. (1994). Active learning through multimedia. IEEE Multimedia, Spring, 69-77.

Schmidt, D. A., Baran, E., Thompson, A. D., Mishra, P., Koehler, M. J., \& Shin, T. S. (2009). Technological pedagogical content knowledge (TPACK): The development and validation of an assessment instrument for preservice teachers. Journal of Research on Technology in Education, 42(2), 123-149.

Shulman, L. S. (1999). Knowledge and teaching: Foundations of the new reform. In J. Leach \& B. Moon (Eds.), Learners and pedagogy (pp. 61-77). London: Paul Chapman Publishing Ltd.

Smeets, E. (2005). Does ICT contribute to powerful learning environments in primary education? Computers \& Education, 44(3), 343-355.

Smeets, E., \& Mooij, T. (2001). Pupil-centred learning, ICT, and teacher behaviour: observations in educational practice. British Journal of Educational Technology, 32(4), 403-417.

Teo, Y. H., \& Ting, B. H. (2010). Singapore education ICT masterplans (1997-2004). In C. S. Chai \& Q. Y. Wang (Eds.), ICT for self-directed and collaborative learning (pp. 2-14). Singapore: Pearson Education South Asia Pte Ltd.

van Olphen, M., Hofer, M., \& Harris, J. (2011, February). World languages learning activity types. Retrieved from Retrieved from College of William and Mary, School of Education, Learning Activity Types Wiki: http://activitytypes.wmwikis.net/file/view/WorldLanguagesLearningATs-Feb2011.pdf

Ward, L., \& Parr, J. M. (2010). Revisiting and reframing use: Implications for the integration of ICT. Computers \& Education, 54(1), 113-122.

Weber, R. P. (1990). Basic content analysis. Newbury Park, California: SAGE Publications.

Windschitl, M. (2002). Framing constructivism in practice as the negotiation of dilemmas: An analysis of the conceptual, pedagogical, cultural, and political challenges facing teachers. Review of Educational Research, 72(2), 131-175.

Windschitl, M. (2004). What types of knowledge do teachers use to engage learners in "doing science?". Paper commissioned by the National Academy of Sciences. Washington, DC: Board of Science Education. Retrieved February, 20, 2007.

Zimmerman, B. J., \& Campillo, M. (2003). Motivating self-regulated problem solvers. In J. E. Davidson \& R. J. Sternberg (Eds.), The nature of problem-solving (pp. 233-262). New York: Cambridge University Press. 
Australasian Journal of Educational Technology, 2013, 29(6).

Corresponding author: Joyce Hwee Ling Koh, joyce.koh@nie.edu.sg

Australasian Journal of Educational Technology (C) 2013.

Please cite as: Koh, J. H. L. (2013). A rubric for assessing teachers' lesson activities with respect to TPACK for meaningful learning with ICT. Australasian Journal of Educational Technology, 29(6), 887-900. 